\title{
Author's Note: Translations, Transliterations, and Conversation Analysis Transcript Notation
}

All the translations and transliterations (see opposite page) are mine unless otherwise indicated. The translations are not a literal rendering of the text; rather, they are done to convey the mood of the Sufi poems so that the reader can enjoy the emotion of the lyrics as they are sung.

\section{CONVERSATION ANALYSIS TRANSCRIPT NOTATION}

In order to represent some of the qawwālì and sufiāna-kalām contexts, I have adapted the conversation analysis transcript system, ${ }^{1}$ which enables readers to follow the transmission of live speech. I further adapt the system to transcribe the interviews with the musicians. In some of the qawwāli contexts discussed in the earlier part of the study, I adapted the conversation analysis system to capture the turn-taking among the qawwāls.

Letters such as A, B, and C represent the different qawwāls, and lines are numbered according to the pauses in the musicians' narratives and where semantically I find the end of the line. A Panjabi qawwāli sung by Ustad Nusrat Fateh Ali Khan and his ensemble in England in I984 is represented thus: ${ }^{2}$

Io C Sir devĩ te vafā na mang ĩ-ehī pīr Farīd dā dase

I I A Palak palak pardesī-ã̃ kāran--merī akhīã ne savāṇ lāe

I2 B Palak palak pardesī-ã kāran--merī akhīã ne savāṇ lāe

I3 A Allah jāne-

Io C Give thy head, expect no loyalty in return-

$\mathrm{O}$, this is Farid, the Saint's wisdom 
I I A For the one who went have my eyes shed a monsoon of tears--

I2 B For the one who went have my eyes shed a monsoon of tears--

I 3 A O, God alone knows-

In the transliterations, punctuation is not used to mark conventional grammatical units; rather, the marks attempt to capture characteristics of speech delivery. Thus, I use the following symbols:

// Slash marks represent overlapping utterances in the qawwālì performance, such as when the Sabri Brothers sang a qawwālī in England in I98I using Mira Bai's voice where she expresses her devotion for Khawaja Muinuddin Chishti of Ajmer: ${ }^{3}$

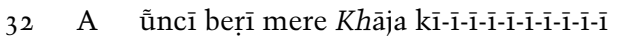

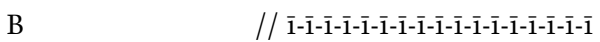

$$
\begin{aligned}
& 32 \text { A } \mathrm{O} \text {, mighty is my Khaja's abode }
\end{aligned}
$$

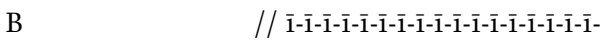

-- Hyphens between the long " $\overline{1}$ "s represent Mira Bai's melismatic cry or other such occurrences in qawwālì. Otherwise a hyphen indicates a short, untimed pause within a sentence.

: Colons indicate an extension of the sound of the syllable they follow:

co: lon Kubra : we we: re going

$$
\begin{array}{ll}
\text { Allāh ho - Nabī:: O ::O} \mathrm{O}^{4} & \text { God ho - Prophet:: O : O } \\
\text { Allāh ho - Nabī:: O :: O } & \text { God ho - Prophet:: O : O } \\
\text { Allāh ho - ho Nabi :: O : O } & \text { God ho - ho Prophet:: O : O }
\end{array}
$$

In the sufiānā-kalām contexts where a solo singer chants, such as Abida Parvin's performance at the Open University auditorium in 1985 that is cited below, ${ }^{5}$ the lines are numbered and the performers are marked with letters. The audience interaction is represented through the overlap symbols (slashes), such as:
A 98 Ik harf iśq dā na paṛh jāṇan
A 99 Bhulan phiran bicāre hū
B $\quad / /$ th $/$ th $/$ th $/$ th [audience claps] ${ }^{6}$
A 98 They can't read a word of love 


\section{AUTHOR'S NOTE \\ $\infty$}

A 99 The poor souls are lost

B $\quad / /$ th $/$ th $/$ th $/$ th [audience claps]

The conversation analysis system was adopted only in the earlier performances that I studied between I985 and I992. I do not follow it in the performances that I transliterated after I992, although I use some conventions from the system in the interviews with the musicians. 
THIS PAGE INTENTIONALLY LEFT BLANK 